EUROPE AT WAR I600-I650 


\section{By the same author}

EUROPE IN THE SEVENTEENTH CENTURY (I966)

GULTURE AND SOGIETY IN

SEVENTEENTH CENTURY FRANCE (I970)

EUROPE IN THE SIXTEENTH GENTURY (I973) 


\title{
Europe at War $1600-1650$
}

\author{
DAVID MALAND, M.A.
}

HIGH MASTER OF THE MANCHESTER GRAMMAR SCHOOL ENGLAND 


\section{(C) David Maland 1980}

All rights reserved. No part of this publication may be reproduced or transmitted, in any form or by any means, without permission.

First published 1980 by

THE MACMILLAN PRESS LTD

London and Basingstoke

Associated companies in Delhi Dublin

Hong Kong Johannesburg Lagos Melbourne

New York Singapore and Tokyo

\section{British Library Cataloguing in Publication Data}

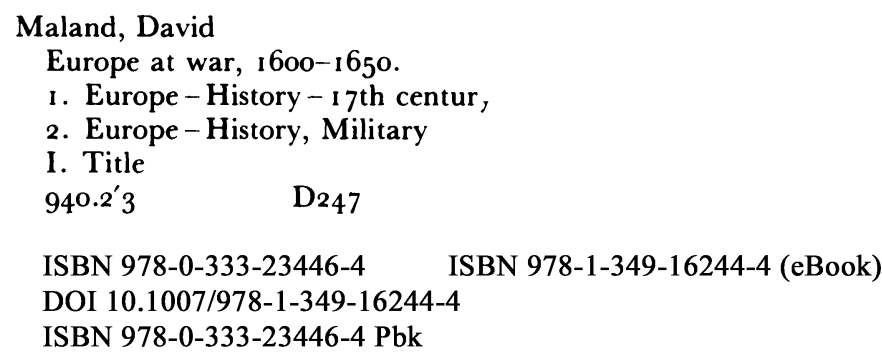

This book is sold subject to the standard conditions of the Net Book Agreement.

The paperback edition of this book is sold subject to the condition that it shall not, by way of trade or otherwise, be lent, re-sold, hired out, or otherwise circulated without the publisher's prior consent in any form of binding or cover other than that in which it is published and without a similar condition including this condition being imposed on the subsequent purchaser. 


\section{Contents}

List of Maps vii

Foreword viii

Introduction: Spain, the Netherlands and Europe I

I AREAS OF CONFLICT I590-1609 12

The Holy Roman Empire $\quad 12$

The 'hereditary lands': Austria, Hungary and Bohemia 18

$\begin{array}{ll}\text { Poland and Sweden } & 21\end{array}$

$\begin{array}{ll}\text { Northern Italy } & 24\end{array}$

$\begin{array}{ll}\text { The Netherlands } & 27\end{array}$

Negotiating the Twelve Years Truce 34

2 EUROPE DURING THE TWELVE YEARS TRUCE I609-2I 40

The problem of Jülich-Cleves $1609^{-1} 4 \quad 40$

Trade, religion and politics in the United Provinces 44

Sweden, Denmark, Russia and Poland 52

Spanish lines of communication $\quad 55$

Bohemia, Hungary and Austria I609-18 60

From the death of Matthias (I6I9) to the Treaty of Ulm (I620) 65

Campaigns in the Rhineland and Bohemia 1620-I 75

The Spanish and Dutch debates on the ending of the Truce $\quad 78$ 


\section{THE SEVEN FAT YEARS OF THE HABSBURGS}

$$
\text { I62I-8 }
$$

Summer 1621 to spring 1622 85

Spring 1622 to autumn 1624 92

Autumn 1624 to autumn 1625

Autumn 1625 to autumn 1627

Autumn 1627 to midsummer 1628

4 THE SEVEN LEAN YEARS OF THE HABSBURGS I628-35

July 1628 to December ${ }_{1629}$

\section{THE EUROPEAN WAR I635-45}

May 1635 to April ${ }_{16} 68$

April 1638 to May 1643: II, the emperor, the Empire and Sweden

June 1643 to August 1645

\section{THE MAKING OF SETTLEMENTS $1645-60$}

The conclusion of the Eighty Years War $1645-48$

The making of the Peace of Westphalia $1645-54$

Postscript I: The United Provinces and the Treaty of

Westminster ${ }_{1} 654$

Postscript II: Sweden and the Treaties of Copenhagen and Oliva 1660

Postscript III: France and the Treaty of the Pyrenees 1659 


\section{List of Maps}

I The Dutch revolt

2 Spanish lines of communication to the Netherlands 8

3 The Holy Roman Empire before I6og 16

4 The Baltic powers 23

5 The Valtelline $\quad 26$

6 The war in the Netherlands $1600-09$ ( 1609 boundaries) 30

7 Jülich-Cleves 40

8 Savoy and northern Italy 57

9 The Bohemian revolt $\quad 64$

Io The Palatinate campaign 74

I I Bohemia and its neighbours $\quad 89$

12 The Rhineland campaign 93

13 The war in the Netherlands $162 \mathrm{I}-48$

14 The campaigns in central Europe $1626-8 \quad 108$

I5 The campaigns in central Europe 1629-34 I3 I

I6 The campaigns in France, the Rhineland and the Netherlands 1635-43 150

I7 Spain and Portugal $\quad$ I58

I8 The campaigns in central Europe $1635-43 \quad 165$

19 Denmark and Sweden 170

20 The making of the Peace of Westphalia 184

21 Brandenburg $1648-60 \quad 185$

22 French gains on the north-eastern frontier $1643-59 \quad$ I 86

23 The Swedish Empire in the Baltic 16 10-6o 196 


\section{Foreword}

This is very much an exercise in story-telling. No one with a school to run, and only a modest repertory of languages, could hope to offer original research in so wide a field as the Thirty Years War; but, by going over the story each year with my pupils, and by reflecting upon it at unwonted leisure throughout the Michaelmas Term of 1975 - thanks to the generosity of the Warden and Fellows of Merton College, Oxford, the Provost and Fellows of the Midland Division of the Woodard Corporation and the Custos and School Council of Denstone College - I believe that the story may gain by being retold with a different emphasis.

I am profoundly grateful to Bartle Frere, who read the manuscript and was unfailingly helpful in his advice and encouragement. 